\title{
Article
}

\section{BDNF/TrkB Signaling as a Potential Novel Target in Pediatric Brain Tumors: Anticancer Activity of Selective TrkB Inhibition in Medulloblastoma Cells}

Thomaz, Amanda, Jaeger, Mariane, Buendia, Marienela, BambiniJunior, Victorio, Gregianin, Lauro José, Brunetto, Algemir Lunardi, Brunetto, André T., de Farias, Caroline Brunetto and Roesler, Rafael

Available at http://clok.uclan.ac.uk/18496/

Thomaz, Amanda, Jaeger, Mariane, Buendia, Marienela, Bambini-Junior, Victorio ORCID: 0000-0002-8590-6770, Gregianin, Lauro José, Brunetto, Algemir Lunardi, Brunetto, André T., de Farias, Caroline Brunetto and Roesler, Rafael (2016) BDNF/TrkB Signaling as a Potential Novel Target in Pediatric Brain Tumors: Anticancer Activity of Selective TrkB Inhibition in Medulloblastoma Cells. Journal of Molecular Neuroscience, 59 (3). pp. 326 333. ISSN 0895-8696

It is advisable to refer to the publisher's version if you intend to cite from the work. http://dx.doi.org/10.1007/s12031-015-0689-0

For more information about UCLan's research in this area go to

http://www.uclan.ac.uk/researchgroups/ and search for <name of research Group>.

For information about Research generally at UCLan please go to http://www.uclan.ac.uk/research/

All outputs in CLoK are protected by Intellectual Property Rights law, including Copyright law. Copyright, IPR and Moral Rights for the works on this site are retained by the individual authors and/or other copyright owners. Terms and conditions for use of this material are defined in the policies page. 
Journal of Molecular Neuroscience

Brief Communication

\title{
BDNF/TrkB Signaling as a Potential Novel Target in Pediatric Brain
}

Tumors: Anticancer Activity of Selective TrkB Inhibition in Medulloblastoma Cells

\author{
Amanda Thomaz - Mariane Jaeger - Marienela Buendia - Victorio Bambini- \\ Junior • Lauro José Gregianin • Algemir Lunardi Brunetto • André T. Brunetto • \\ Caroline Brunetto de Farias • Rafael Roesler
}

Amanda Thomaz • Mariane Jaeger • Marienela Buendia • Lauro José Gregianin • Algemir Lunardi Brunetto • André T. Brunetto • Caroline Brunetto de Farias • Rafael Roesler

Cancer and Neurobiology Laboratory, Experimental Research Center, Clinical Hospital (CPE-HCPA), Federal University of Rio Grande do Sul, 90035-003 Porto Alegre, RS, Brazil

Amanda Thomaz $\bullet$ Mariane Jaeger $\bullet$ Marienela Buendia $\bullet$ Rafael Roesler 
Department of Pharmacology, Institute for Basic Health Sciences, Federal University of Rio Grande do Sul, 90050-170 Porto Alegre, RS, Brazil

\author{
Victorio Bambini-Junior \\ Laboratory of Thymus Research, Oswaldo Cruz Institute, Oswaldo Cruz Foundation, \\ 21040-360 Rio de Janeiro, RJ, Brazil
}

Lauro José Gregianin

Department of Pediatrics, Faculty of Medicine, Federal University of Rio Grande do Sul, 90035-003 Porto Alegre, RS, Brazil

Children's Cancer Institute (ICI), 90420-140 Porto Alegre, RS, Brazil

Algemir Lunardi Brunetto • André T. Brunetto • Caroline Brunetto de Farias

Correspondence to: Rafael Roesler, Department of Pharmacology, Institute for Basic Health Sciences, Federal University of Rio Grande do Sul, Rua Sarmento Leite, 500 (ICBS, Campus Centro/UFRGS), 90050-170 Porto Alegre,RS, Brazil.

Tel.: +5551 33083183; fax: +555133083121.

E-mail address: rafael.roesler@pq.cnpq.br (R. Roesler). 


\section{Abstract}

Medulloblastoma (MB) is the most common malignant pediatric brain tumor. Deregulation of BDNF/TrkB signaling has been associated with increased proliferative capabilities, invasiveness and chemo-resistance in several types of cancer. However, the relevance of this pathway in $\mathrm{MB}$ remains unknown. Here, we show that the selective TrkB inhibitor ANA-12 markedly reduced the viability and survival of human cell lines representative of different $\mathrm{MB}$ molecular subgroups. These findings provide the first evidence supporting further investigation of TrkB inhibition as a potential novel strategy for MB treatment.

Keywords TrkB • Brain-derived neurotrophic factor $\bullet$ Medulloblastoma $\bullet$ Brain tumor $\bullet$ Childhood cancer 


\section{Introduction}

Brain tumors represent the main leading cause of cancer-related death in childhood. Medulloblastoma (MB), the most common type of brain cancer afflicting children, is an embryonal solid tumor that usually arises in the cerebellum and spreads through the cerebrospinal fluid (CSF), leading to metastasis (Brandes et al. 2015; Roussel et al. 2011). The use of next-generation sequencing and other advanced molecular biology approaches has recently revolutionized our understanding of MB biology, leading to the current consensus that $\mathrm{MB}$ represents a heterogeneous group of tumors that can be divided into four distinct molecular subgroups - WNT, SHH, Group 3 and Group 4 (Taylor et al. 2012). MB subgroups display distinct cellular origins, mutations, gene expression signatures, methylation profiles as well as clinical course (Northcott et al. 2012; Rusert et al. 2014.). Despite the remarkable recent advances in the understanding of MB biology, one-third of patients still have low chance of being cured. Contemporary therapeutic approaches are highly toxic, and survivors often suffer from treatment-related neurological disabilities (Samkari et al. 2015). Therefore, the development of novel specific therapies is urgently needed.

Emerging therapeutic targets for cancer treatment include receptors for neurotrophins (NT), which are also important for the normal development and function of the CNS. The activities of NTs are mediated by NGF, BDNF, NT-3 and NT-4/5 binding to their related tropomyosin kinase receptors, TrkA, TrkB and $\operatorname{TrkC}$ respectively (Huang and Reichardt 2003; Nakagawara, 2001). Trk activation or mutations have been detected in several types of cancer, including tumors of neural origin, such as neuroblastoma and MB (Thiele et al. 2009; Tan et al. 2014). BDNF and 
TrkB overexpression or TrkB activation have been characterized in neuroblastoma (Brodeur et al. 2009), lung (Sinkevicius et al. 2014), colorectal (de Farias et al. 2010), prostate (Bronzetti et al. 2008) and breast cancers (Vanhecke et al. 2011). TrkB-positive cells are linked to increased proliferative capabilities, anoikis resistance, metastasis, invasiveness and chemo- resistance (de Farias et al. 2012; Desmet and Pepper, 2006; Li et al 2007; Thiele et al. 2009.

Expression of BDNF and TrkB has been detected in both MB tumor samples and MB cell lines (Chou et al. 1997; Schmidt et al. 2010). Previous reports have shown that, under certain experimental conditions, human recombinant BDNF alone or in combination of HDAC inhibitors, is able to decrease cell viability in MB cell lines (Nör et al. 2011; Schmidt et al. 2010). However, the biological role and clinical significance of $\mathrm{BDNF} / \mathrm{TrkB}$ signaling in $\mathrm{MB}$ remain poorly understood, and previous studies have not verified whether TrkB inhibition affects MB growth.

A small-molecule selective TrkB inhibitor, ANA-12, has been recently developed and has become a useful tool for examining the involvement of BDNF/TrkB signaling in physiological and pathological processes (Cazorla et al. 2011). Here, we investigated the effects of ANA-12 in human pediatric MB cell lines representative of different molecular subgroups. ANA-12 reduced cell viability and clonogenic survival in a dose-dependent manner. These findings provide the first evidence suggesting TrkB inhibition as a potential targeted therapy for MB. 


\section{Materials and Methods}

\section{Reagents}

ANA-12 (N-[2-[[(Hexahydro-2-oxo-1H-azepin-3-yl) amino] carbonyl] phenyl]-benzo [b] thiophene-2-carboxamide), human recombinant BDNF, and dimethyl sulfoxide (DMSO) were purchased from Sigma-Aldrich Chemical Co. (St. Louis, MO, USA). Annexin V-FITC was obtained from Santa Cruz Biotechnology (Dallas, TX, USA.). Propidium iodide (PI), trizol, SuperScript ${ }^{\circledR}$ III Reverse Transcriptase and low DNA mass ladder were provided by Invitrogen-Life technologies (Carlsbad, CA, USA). GoTaq® Hot Start Polymerase and RQ1 RNase-Free DNase were supplied by Promega (Madison, WI, USA). Ethidium bromide was purchased from Biotium (Hayward, USA). All culture materials were obtained from Gibco-Life technologies (Grand Island, NY, USA). Cisplatin was donated by the Kaplan Oncology Institute (Porto Alegre, Brazil).

\section{Cell Culture and Treatments}

Human MB cell lines Daoy, D283, ONS-76 and UW-228 were kindly donated by Dr. Michael D. Taylor (The Hospital for Sick Children, Toronto, Canada). Daoy, D283 and ONS-76 cells were cultured in Dulbecco's modified Eagle's medium (DMEM) low glucose, while UW-228 cell was cultured in DMEM: Nutrient Mixture F-12 (DMEM/F12), both media supplemented with $10 \%(\mathrm{v} / \mathrm{v})$ fetal bovine serum (FBS) and 1\% (v/v) 
penicillin/streptomycin. Cells were incubated in a humidified atmosphere of $5 \% \mathrm{CO}_{2}$ at $37^{\circ} \mathrm{C}$

Cells were treated with increasing concentrations of ANA-12 $(5,20$ or $30 \mu \mathrm{M})$ or BDNF $(50 \mathrm{ng} / \mathrm{ml})$ in complete medium for 48 hours. ANA-12 was dissolved in DMSO. The concentration of the vehicle DMSO was used as control and did not exceed $0.5 \%(\mathrm{v} / \mathrm{v})$. ANA-12 concentrations were based in a previous in vitro study using this inhibitor (Sinkevicius et al. 2014).

\section{Cell Viability}

Cell viability was assessed by trypan blue cell counting as described previously (Jaeger et al. 2013; Nör et al. 2011). Daoy, ONS-76, UW-228 and D283 cells were seeded at a density of $3 \times 10^{3}$ cells per well in complete medium into 96-well plates (TPP® Switzerland). After overnight culture in complete medium, cells were treated with ANA-12. After 48 hours of treatment, the medium was removed, cells were washed with PBS and $50 \mu \mathrm{l}$ of $0.25 \%$ trypsin/EDTA solution was added to detach cells. Cell suspension was homogenized with $0.4 \%$ Trypan blue $1: 1$ and counted immediately in a hemocytometer. Experiments were performed at least four times in quadruplicates for each treatment. Cell viability was normalized to the control DMSO.

\section{Cell Survival}


For evaluation of cell survival, UW-228 and D283 cells were plated at 400 cells per well in six-well plates (NEST®, China). Cells were allowed to adhere and then were incubated overnight in complete medium at $37^{\circ} \mathrm{C}$, and were then exposed to ANA-12 or BDNF. After $48 \mathrm{~h}$ the cells were washed with standard medium to remove ANA-12 or BDNF and cultured for another week, with the medium being changed every 2 days. Cells were then fixed with $70 \%$ ethanol and counterstained with $0.5 \%$ crystal violet. Colony numbers and colony size were assessed by ImageJ plugin, "ColonyArea" as previously described by Guzmán et al (2014).

\section{Cell Cycle}

UW-228 cell was plated at $15 \times 10^{3}$ cells per well in 24 -well plate (NEST®, China), followed by drug treatments as describe above. After $48 \mathrm{~h}$ of treatment, both floating and attached cells were harvested, washed twice with PBS and marked with a solution containing $50 \mu \mathrm{g} / \mathrm{ml}$ PI, $0.1 \%$ Triton $\mathrm{X}-100$ and $0,1 \%$ sodium citrate for $15 \mathrm{~min}$, in the dark, at room temperature. Cells were analyzed by flow cytometer (Attune ${ }^{\circledR}$ applied biosystems). Single cells were gated using width and area parameters. An area parameter histogram was used to determine the percentage of cells in Sub-G1/G0, G1, S and $\mathrm{G} 2$ phases.

\section{Reverse Transcriptase Polymerase Chain Reaction (RT-PCR)}


Total RNA from UW-228 cell was extracted using trizol reagent, in accordance with the manufacturer's instructions, quantified in NanoDrop (Thermo Scientific), treated with DNase and reverse-transcribed with superscript ${ }^{\circledR}$ III First-Strand Synthesis supermix. BDNF, TrkB and $\beta$-actin primers used for RT-PCR amplification were designed according to the corresponding GenBank sequence and are shown in Table 1. The expression of $\beta$-actin was measured as an internal control.

PCR conditions for experiments were $1.5 \mathrm{mM} \mathrm{MgCl} 2,0.4 \mu \mathrm{M}$ for each primer, 0.2 dNTPs, $1.25 \mathrm{u}$ GoTaq ${ }^{\circledR}$ Hot Start Polymerase, and $1 \mu \mathrm{l}$ cDNA template. All assays were carried out in a total volume of $15 \mu \mathrm{l}$ using 35 cycles for amplification that consisted of $1 \mathrm{~min}$ at $95{ }^{\circ} \mathrm{C}$, denaturation at $94{ }^{\circ} \mathrm{C}$ for $30 \mathrm{~s}$, annealing at $58-60{ }^{\circ} \mathrm{C}$, accordingly to the specific primer, for $30 \mathrm{~s}$, and extension of primers at $72{ }^{\circ} \mathrm{C}$ for $45 \mathrm{~s}$, followed by a final extension at $72{ }^{\circ} \mathrm{C}$ for $10 \mathrm{~min}$. The products of BDNF, TrkB and $\beta$ actin were electrophoresed through $1.5 \%$ agarose gels containing ethidium bromide and visualized with ultraviolet light. The fragments' length was confirmed using a low DNA mass ladder. For each set of PCR reactions, a negative control was included.

\section{Statistical Analysis}

Data are shown as mean \pm standard error of mean (SEM). Statistical analysis was performed by one-way analysis of variance (ANOVA) followed by tukey post-hoc test for multiple comparisons of at least three independent experiments for each experiments; $P$ values under 0.05 was considered significant. Analyses were conducted using the GraphPad Prism 6 software (GraphPad Software, San Diego, CA, USA). 


\section{Results}

\section{TrkB Inhibition Reduces MB Cell Viability}

The cytotoxic activity of the selective TrkB inhibitor ANA-12 was evaluated by trypan blue cell counting assay at 48 hours under standard growth conditions (Fig. 1). Analysis with ANOVA indicated that ANA-12 produced a reduction of MB cell viability at all doses tested $(\mathrm{F}=2.182, \mathrm{df}=9, P=0.0392)$. Further analysis with Tukey tests comparing control and drug-treated cells showed that ANA-12 at $5 \mu \mathrm{M}$ was ineffective in ONS-76, UW-228 and Daoy cells, but significantly reduce cell viability in D283 cells $(29.8 \pm 9.03 \% ; P<0.01)$. Treatment with ANA-12 at $20 \mu \mathrm{M}$ reduced viability in all cell lines (ONS-76: $62.95 \pm 4.8 \%, p<0.001 ; \mathrm{UW}-228: 57.69$ $\pm 5.3 \%, P<0.001$; Daoy: 59.41 $\pm 9.27 \%, P<0.01$; D283 $62.51 \pm 4.08 \%, P<$ $0.0001)$. The maximal decrease in cell viability was produced by ANA-12 at $30 \mu \mathrm{M}$ (ONS-76: $75.43 \pm 6.9 \%, P<0.0001$; UW-228: $94.80 \pm 4.16 \%, P<0.001$; Daoy: $90.10 \pm 3.52 \%, P<0.001 ; \mathrm{D} 283: 93.58 \pm 0.82 \%, P<0.0001)$. 


\section{TrkB Inhibition Reduces MB Cell Survival}

The effects of ANA-12 and BDNF on colony formation were analyzed in UW-228 and D283 cells (Fig. 2). ANA-12 reduced colony formation in both cell lines over one week, after $48 \mathrm{~h}$ of treatment. BDNF alone did not affect colony formation. In UW-228 cells, ANA-12 decreased colony number at $20 \mu \mathrm{M}(10.53 \pm 5.69 \%, P<0.01)$ and $30 \mu \mathrm{M}$ $(3.03 \pm 0.87 \%, P<0.001)$, when compared to both control $(33.4 \pm 1.75 \%)$ and BDNFtreated cells $(21.26 \pm 3.91 \%)$, whereas colony size was not significantly affected (Fig. 2a, 2c). In D283 cells, colony number was reduced only by the dose of $30 \mu \mathrm{M}$ of ANA$12(3.76 \pm 2.39 \%, P<0.05)$ when compared with eiher control $(22.71 \pm 5.09 \%)$ or BDNF-treated cells $(22.16 \pm 2.42 \%)$. This dose of ANA-12 also decreased colony size $(1.53 \pm 0.99 \%, P<0.05)$ in comparison with either control cells $(9.94 \pm 2.51 \%)$ and cells exposed to BDNF $(10.03 \pm 1.66 \%)$ (Fig. 2b, 2d). 


\section{TrkB Inhibition alters MB cell cycle}

UW-228 cells were used to assess cell cycle distribution after 48h of ANA-12 treatment. ANA-12 induced sub-G1 cell cycle arrest in a dose-dependent manner (Fig. 3). Intracellular PI fluorescence intensities are presented (Fig. 3a) and the percentage of cells in the sub-G1 phase was significantly increased after treatment with ANA-12 at 30 $\mu \mathrm{M}$ (sub G1: $17.3 \pm 3.99 \%, P<0.001$ ) compared to either controls (sub-G1: $1.73 \pm$ $0.07 \%$ ) and BDNF-treated cells (sub-G1: $1.09 \pm 0.55 \%$ ). In addition, the percentage of cells in the G1 phase was inhibited by ANA-12 at $30 \mu \mathrm{M}$ (G1: $36.86 \pm 4.57 \%, P<$ 0.001) compared to controls (G1: $65.3 \pm 4.90 \%)$ and BDNF-treated cells (G1: $64.50 \pm$ 2.83\%) (Fig. 3b). BDNF alone did not affect the cell cycle. These data suggest that ANA-12 induced cell cycle arrest in UW-228 cell.

\section{UW-228 MB cells express mRNA for TrkB and BDNF}

Reverse transcriptase polymerase chain reaction (RT-PCR) analysis confirmed that UW-228 cell express mRNA for BDNF and TrkB. Two transcripts with 130 bp and 123 bp of size, representing a fragment of TrkB and BDNF respectively, were identified (Fig. 3c). BDNF and TrkB expression for Daoy, D283 and ONS-76 MB cells were demonstrated in previous reports (Nör et al. 2011; Schmidt et al. 2010). 


\section{Discussion}

Aggressive multimodal therapy in MB patients is generally associated with long term side effects, therefore novel antitumor strategies targeting deregulated pathways need to be explored (Gottardo et al. 2014). Given that BDNF/TrkB signaling has been shown to promote tumor cell proliferation, survival and increase chemo-resistance in several type of cancers (Tan et al. 2014), we hypothesized that this pathway could regulate cell viability in pediatric MB. To study BDNF/TrkB signaling in MB cells, we employed a small molecule, ANA-12, which blocks TrkB selectively (Cazorla et al. 2011). We used MB cell lines that were recently characterized as representative of different MB molecular subgroups lines representative of different molecular groups of MB. Daoy, ONS-76 and UW-228 cells show features of SHH tumors, whereas D283 displays MYC amplification and is classified as Group $3 \mathrm{MB}$ subgroup 3 (Xu et al. 2015). Our results indicate that TrkB inhibition can reduce cell viability and survival of MB cells.

The suggestion that $\mathrm{BDNF} / \mathrm{TrkB}$ might be relevant in MB first came from early studies examining this pathway in tumor samples and cell lines. Segal et al. (1994) found that the level of TrkB mRNA expression was not associated with extent of disease progression or patient survival. Washiyama et al. (1996) evaluated 27 samples from $\mathrm{MB}$ patients and found $67 \%$ of tumors expressing TrkB and $22 \%$ expressing BDNF. However, the molecular classification of MB was only recently defined $(\mathrm{Xu}$ et al. 2015), and the relationship between expression levels of NTs and Trk receptors in different subgroups remains to be characterized. Expression of BDNF and TrkB was previously identified in Daoy, ONS-76 and D283 cell lines (Schmidt et al. 2010), and in 
the present study we demonstrate that UW-228 cell likewise express mRNA for both TrkB and BDNF.

The present report is the first demonstration that selective TrkB inhibition displays antitumor effect in MB cells. Moreover, it was previously demonstrated that a pan-Trk inhibitor can reduce MB xenografts growth (Evans et al. 1999). Because we did not aim to address candidate downstream signaling components possibly involved in mediating the effects, any discussion of mechanisms remain speculative at this point. TrkB activation initiate multiple signaling cascades, including mitogen-activated protein kinase (MAPK) pathway, phosphatidyl-inositide 3-kinase (PI3K) pathway, and phospholipase C-gamma (PLC- $\gamma$ ). All these pathways play important roles in cell proliferation, differentiation and survival, consistent with a role for $\operatorname{TrkB}$ in these cellular processes (Boulle et al. 2012).

The sub-G1 accumulation observed in cell cycle analyses may be related to apoptotic cells, which can be identified on DNA frequency histograms as cells with fractional DNA content (Kajstura et al. 2007). A previous report using leukemia cells found apoptosis and reduction of GSK-3 $\beta$ phosphorylation after ANA-12 treatment (Polakowski et al. 2014). In neurons, GSK-3 $\beta$ activation counteracts the effects of BDNF, and specific downstream signaling of TrkB phosphorylation pathway converge to the inactivation of GSK-3 $\beta$ (Phukan et al. 2010). The involvement of GSK-3 $\beta$ in a variety of cellular responses, including cytoskeleton regulation, cell cycle progression, apoptosis and cell adhesion, is well established (McCubrey et al. 2014). It has been also postulated that constitutive phosphorylation of GSK-3 $\beta$, found in many tumor cell types, including $\mathrm{MB}$, improves cell survival and contributes to malignant transformation 
(Urbanska et al. 2007). However, the functional role of ANA-12 in apoptosis of MB cells remains to be characterized.

In summary, the present study found pronounced dose-dependent inhibitory effects of a selective TrkB inhibitor, ANA-12, on cell viability and survival in pediatric MB cell lines in vitro. These results provide the first evidence that selective TrkB inhibition may be a promising strategy worth further investigation in experimental MB.

\section{Acknowledgements}

This research was supported by the National Council for Scientific and Technological Development (CNPq; grant numbers 484185/2012-8 and 303276/2013-4 to R.R.); PRONON/Ministry of Health, Brazil (number 25000.162.034/2014-21 to C.B.F); and the Rafael Koff Acordi Research Fund, Children's Cancer Institute (ICI). 


\section{References}

Boulle F, Kenis G, Cazorla M, Hamon M, Steinbusch HW, Lanfumey L, van den Hove DL (2012) TrkB inhibition as a therapeutic target for CNS-related disorders. Prog Neurobiol 98: 197-206.

Brandes AA, Bartolotti M, Marucci G, Ghimenton C, Agati R, Fioravanti A, Mascarin M, Volpin L, Ammannati F, Masotto B, Gardiman MP, De Biase D, Tallini G, Crisi G, Bartolini S, Franceschi E (2015) New perspectives in the treatment of adult medulloblastoma in the era of molecular oncology. Crit Rev Oncol Hematol 94: 348-359.

Brodeur GM, Minturn JE, Ho R, Simpson AM, Iyer R, Varela CR, Light JE, Kolla V, Evans AE (2009) Trk receptor expression and inhibition in neuroblastomas. Clin Cancer Res 15: 3244-3250.

Bronzetti E, Artico M, Forte F, Pagliarella G, Felici LM, D'Ambrosio A, Vespasiani G, Bronzetti B (2008) A possible role of BDNF in prostate cancer detection. Oncol Rep 19: 969-974.

Cazorla M, Prémont J, Mann A, Girard N, Kellendonk C, Rognan D (2011) Identification of a low-molecular weight TrkB antagonist with anxiolytic and antidepressant activity in mice. J Clin Invest 121: 1846-1857.

Chou TT, Trojanowski JQ, Lee VM (1997) Neurotrophin signal transduction in medulloblastoma. J Neurosci Res 49: 522-527.

de Farias CB, Heinen TE, dos Santos RP, Abujamra AL, Schwartsmann G, Roesler R (2012) BDNF/TrkB signaling protects HT-29 human colon cancer cells from EGFR inhibition. Biochem Biophys Res Commun 425: 328-332. 
de Farias C, Rosemberg DB, Heinen TE, Koehler-Santos P, Abujamra AL, Kapczinski F, Brunetto AL, Ashton-Prolla P, Meurer L, Reis Bogo M, Damin DC, Schwartsmann G, Roesler R (2010) BDNF/TrkB content and interaction with gastrin-releasing peptide receptor blockade in colorectal cancer. Oncology 79: 430-439.

Desmet CJ, Peeper DS (2006) The neurotrophic receptor TrkB: a drug target in anticancer therapy? Cell Mol Life Sci 63: 755-759.

Evans AE, Kisselbach KD, Yamashiro DJ, Ikegaki N, Camoratto AM, Dionne CA, Brodeur GM (1999) Antitumor activity of CEP-751 (KT-6587) on human neuroblastoma and medulloblastoma xenografts. Clin Cancer Res 5: 3594-3602.

Gottardo NG, Hansford JR, McGlade JP, Alvaro F, Ashley DM, Bailey S, Baker DL, Bourdeaut F, Cho YJ, Clay M, Clifford SC, Cohn RJ, Cole CH, Dallas PB, Downie P, Doz F, Ellison DW, Endersby R, Fisher PG, Hassall T, Heath JA, Hii HL, Jones DT, Junckerstorff R, Kellie S, Kool M, Kotecha RS, Lichter P, Laughton SJ, Lee S, McCowage G, Northcott PA, Olson JM, Packer RJ, Pfister SM, Pietsch T, Pizer B, Pomeroy SL, Remke M, Robinson GW, Rutkowski S, Schoep T, Shelat AA, Stewart CF, Sullivan M, Taylor MD, Wainwright B, Walwyn T, Weiss WA, Williamson D, Gajjar A (2014) Medulloblastoma Down Under 2013: a report from the third annual meeting of the International Medulloblastoma Working Group., Acta Neuropathol 127: 189-201.

Guzmán C, Bagga M, Kaur A, Westermarck J, Abankwa D (2014) ColonyArea: an ImageJ plugin to automatically quantify colony formation in clonogenic assays., PLoS One 9: e92444. 
Huang EJ, Reichardt LF (2003) Trk receptors: roles in neuronal signal transduction. Annu Rev Biochem 72: 609-642.

Jaeger M, Nör C, de Farias CB, Abujamra AL, Schwartsmann G, Brunetto AL, Roesler R (2013) Anti-EGFR therapy combined with neuromedin B receptor blockade induces the death of DAOY medulloblastoma cells. Childs Nerv Syst 29: 21452150.

Kajstura M, Halicka HD, Pryjma J, Darzynkiewicz Z (2007) Discontinuous fragmentation of nuclear DNA during apoptosis revealed by discrete "sub-G1" peaks on DNA content histograms. Cytom Part A 71A: 125-131.

Li Z, Zhang J, Liu Z, Woo CW, Thiele CJ (2007) Downregulation of Bim by brainderived neurotrophic factor activation of TrkB protects neuroblastoma cells from paclitaxel but not etoposide or cisplatin-induced cell death. Cell Death Differ 14: 318-326.

McCubrey JA, Steelman LS, Bertrand FE, Davis NM, Sokolosky M, Abrams SL, Montalto G, D'Assoro AB, Libra M, Nicoletti F, Maestro R, Basecke J, Rakus D, Gizak A, Demidenko ZN, Cocco L, Martelli AM, Cervello M (2014) GSK-3 as potential target for therapeutic intervention in cancer. Oncotarget 5: 28812911.

Nakagawara A (2001) Trk receptor tyrosine kinases: a bridge between cancer and neural development. Cancer Lett 169: 107-114.

Nör C, de Farias CB, Abujamra AL, Schwartsmann G, Brunetto AL, Roesler R (2011) The histone deacetylase inhibitor sodium butyrate in combination with brainderived neurotrophic factor reduces the viability of DAOY human medulloblastoma cells. Childs Nerv Syst 27: 897-901. 
Northcott PA, Korshunov A, Pfister SM, Taylor MD (2012) The clinical implications of medulloblastoma subgroups., Nat Rev Neurol 8: 340-351.

Phukan S, Babu VS, Kannoji A, Hariharan R, Balaji VN (2010) GSK3beta: role in therapeutic landscape and development of modulators. Br J Pharmacol 160: 119.

Polakowski N, Terol M, Hoang K, Nash I, Laverdure S, Gazon H, Belrose G, Mesnard JM, Césaire R, Péloponèse JM, Lemasson I (2014) HBZ stimulates brainderived neurotrophic factor/TrkB autocrine/paracrine signaling to promote survival of human T-cell leukemia virus type 1-Infected T cells. J Virol 88: $13482-13494$.

Roussel MF, Hatten M.E., Cerebellum development and medulloblastoma. Curr Top Dev Biol 94: 235-282.

Rusert JM, Wu X, Eberhart CG, Taylor MD, Wechsler-Reya RJ (2014) SnapShot: Medulloblastoma. Cancer Cell 26: 940.

Samkari A, White JC, Packer RJ (2015) Medulloblastoma: toward biologically based management. Semin Pediatr Neurol 22: 6-13.

Schmidt AL, de Farias CB, Abujamra AL, Kapczinski F, Schwartsmann G, Brunetto AL, Roesler R (2010) BDNF and PDE4, but not the GRPR, regulate viability of human medulloblastoma cells. J Mol Neurosci 40: 303-310.

Segal RA, Goumnerova LC, Kwon YK, Stiles CD, Pomeroy SL (1994) Expression of the neurotrophin receptor TrkC is linked to a favorable outcome in medulloblastoma. Proc Natl Acad Sci U S A 91: 12867-12871.

Sinkevicius KW, Kriegel C, Bellaria KJ, Lee J, Lau AN, Leeman KT, Zhou P, Beede AM, Fillmore CM, Caswell D, Barrios J, Wong KK, Sholl LM, Schlaeger TM, Bronson RT, Chirieac LR, Winslow MM, Haigis MC, Kim CF (2014) 
Neurotrophin receptor TrkB promotes lung adenocarcinoma metastasis. Proc Natl Acad Sci U S A 111: 10299-10304.

Tan F, Thiele C, Li Z (2014) Neurotrophin signaling in cancer. Handb Neurotox (2014). Taylor MD, Northcott PA, Korshunov A, Remke M, Cho YJ, Clifford SC, Eberhart CG, Parsons DW, Rutkowski S, Gajjar A, Ellison DW, Lichter P, Gilbertson RJ, Pomeroy SL, Kool M, Pfister SM (2012) Molecular subgroups of medulloblastoma: the current consensus. Acta Neuropathol 123: 465-472.

Thiele CJ, Li Z, McKee AE (2009) On Trk--the TrkB signal transduction pathway is an increasingly important target in cancer biology. Clin Cancer Res 15: 5962-5967.

Urbanska K, Trojanek J, Del Valle L, Eldeen MB, Hofmann F, Garcia-Echeverria C, Khalili K, Reiss K (2007) Inhibition of IGF-I receptor in anchorageindependence attenuates GSK-3beta constitutive phosphorylation and compromises growth and survival of medulloblastoma cell lines. Oncogene 26: $2308-2317$.

Vanhecke E, Adriaenssens E, Verbeke S, Meignan S, Germain E, Berteaux N, Nurcombe V, Le Bourhis X, Hondermarck H (2011) Brain-derived neurotrophic factor and neurotrophin- $4 / 5$ are expressed in breast cancer and can be targeted to inhibit tumor cell survival. Clin Cancer Res 17: 1741-1752.

Washiyama K, Muragaki Y, Rorke LB, Lee VM, Feinstein SC, Radeke MJ, Blumberg D, Kaplan DR, Trojanowski JQ (1996) Neurotrophin and neurotrophin receptor proteins in medulloblastomas and other primitive neuroectodermal tumors of the pediatric central nervous system. Am J Pathol 148: 929-940.

Xu J, Margol A, Asgharzadeh S, Erdreich-Epstein A (2015) Pediatric brain tumor cell lines. J Cell Biochem 116: 218-224. 
Table 1. Forward and reverse primers used for RT-PCR amplification

\begin{tabular}{ccc}
\hline Gene & Primer sequence & PCR product size (bp) \\
\hline \multirow{2}{*}{ TrKB } & Forward: 5'-TGGTGCATTCCATTCACTGT-3' & 130 \\
& Reverse:5'-CGTGGTACTCCGTGTGATTG-3' & \\
BDNF & Forward:5'-GGCTATGTGGAGTTGGCATT-3' & 123 \\
& Reverse:5'-CTTCAGAGGCCTTCGTTTTG-3' & \\
& & 190 \\
\hline $\boldsymbol{\beta}$-actin & Forward:5'-GAGACCTTCAACACCCCAG 3' & \\
\hline
\end{tabular}




\section{Legends for figures}

Fig. 1. A TrkB inhibitor dose-dependently reduces MB cell viability. ANA-12 decreased the viability of (a) ONS-76, (b) UW-228, (c) Daoy, and (d) D283 cells. Cells were treated with increasing concentrations of ANA-12. After $48 \mathrm{~h}$ of drug exposure the cell viability was assessed by trypan blue counting assay. Data are expressed by mean \pm SEM percentage of control (the average value among replicates was assumed as $100 \%$ ) and represent four independent experiments performed in quadruplicates. Statistically significant differences are marked by asterisks as follows: ** $P<0.01$, *** $P<0.001$, and $* * * * P<0.0001$.

Fig. 2. TrkB inhibition reduces colony formation in MB cells. UW-228 and D283 cells were exposed to BDNF $(50 \mathrm{ng} / \mathrm{ml})$ or $\mathrm{ANA}-12(5,20$ or $30 \mu \mathrm{M})$ for 48 hours and subsequently maintained in standard growth medium for 7 days. Colony formation and colony size were assessed using ImageJ version $1.47 \mathrm{n}$ software. (a and c) Data are mean \pm SEM \% colony number and colony size. Data represent at least three independent experiments. Statistically significant differences are marked by asterisks, $* P<0.05$ and ** $P<0.01$. (b and d) Representative images of colonies formed under the different treatment conditions.

Fig. 3. TrkB induced sub-G1 cell cycle arrest in UW-228 MB cell. Cells were exposed to BDNF $(50 \mathrm{ng} / \mathrm{ml})$ or ANA-12 $(5,20$ and $30 \mu \mathrm{M})$ for 48 hours and subsequently the 
cell cycle distribution was determined by propidium iodide staining. (a) Representative DNA fluorescence histograms of UW-228 cell following the treatments and control (DMSO). (b) Data are mean \pm SEM $\%$ of cells in each cycle phase. Statistically significant differences are marked by asterisks, $* * * P<0.001$. The data represents three independent experiments. (c) UW-228 MB cell express TrkB and BDNF. mRNA was extracted from UW-228 cells and RT-PCR was performed. A transcript with $130 \mathrm{bp}$, representing a fragment of TrkB gene, was identified. A transcript with $123 \mathrm{bp}$, representing a fragment of BDNF, was identified. B-actin was used as control. 

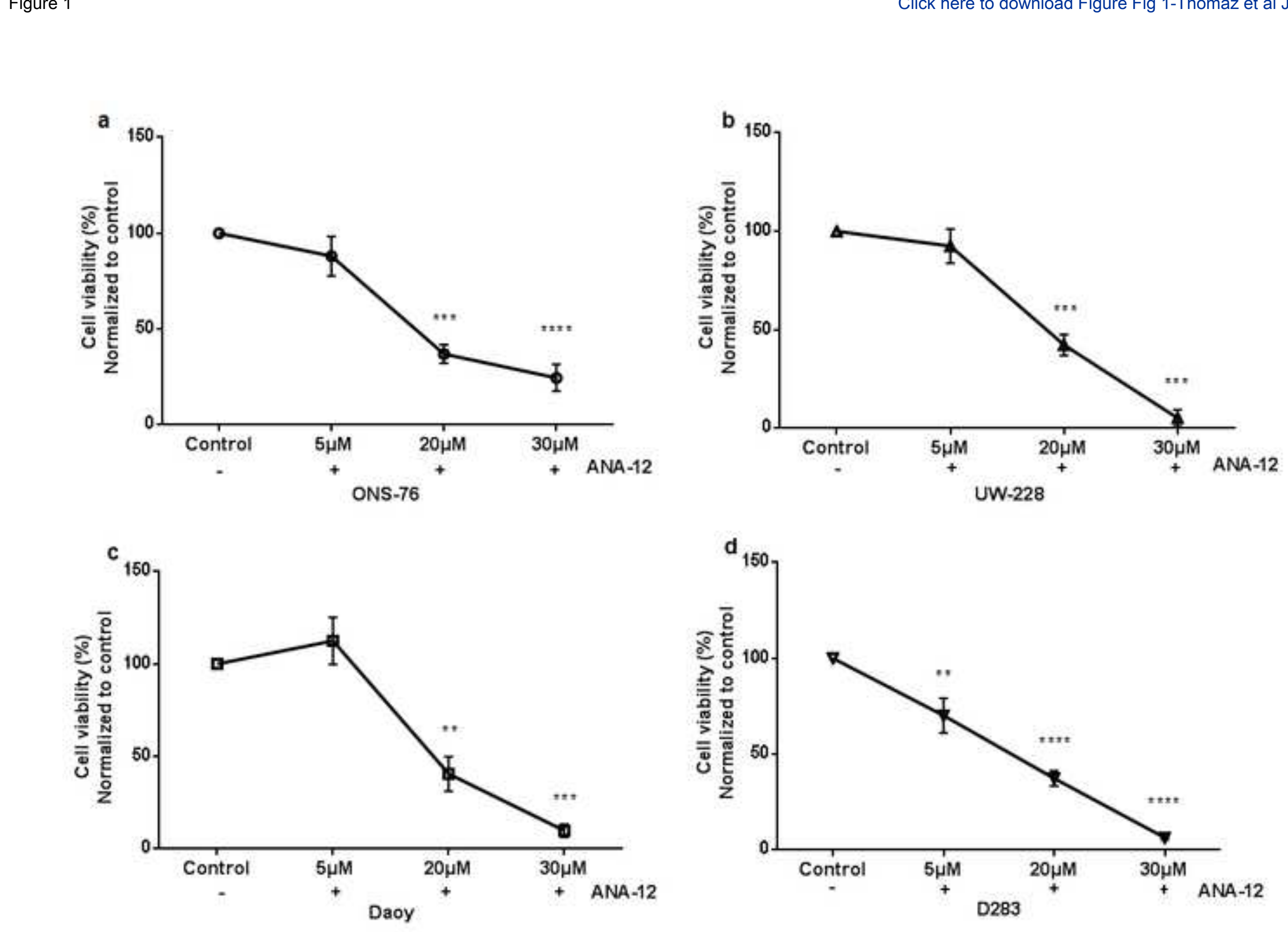

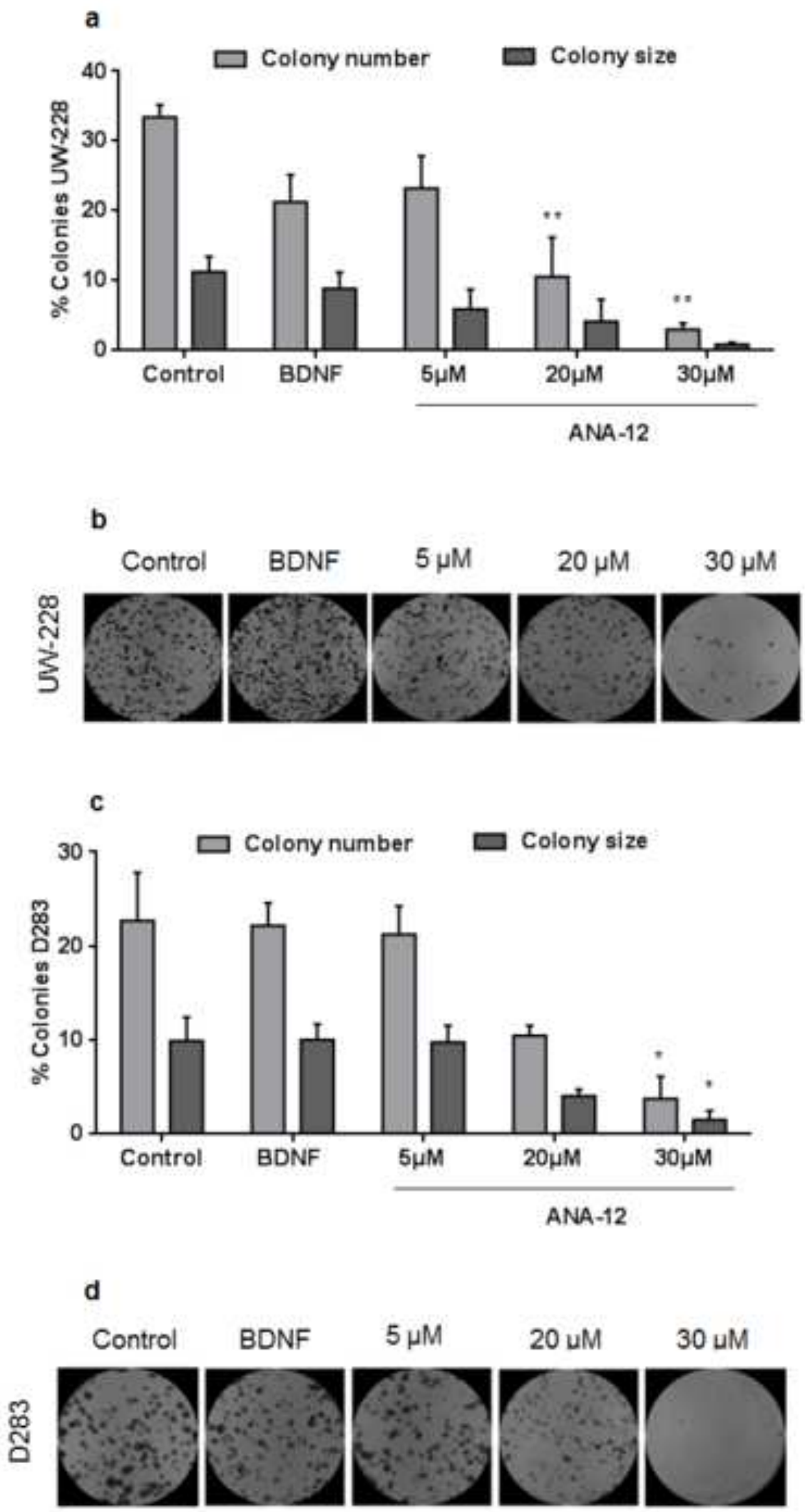

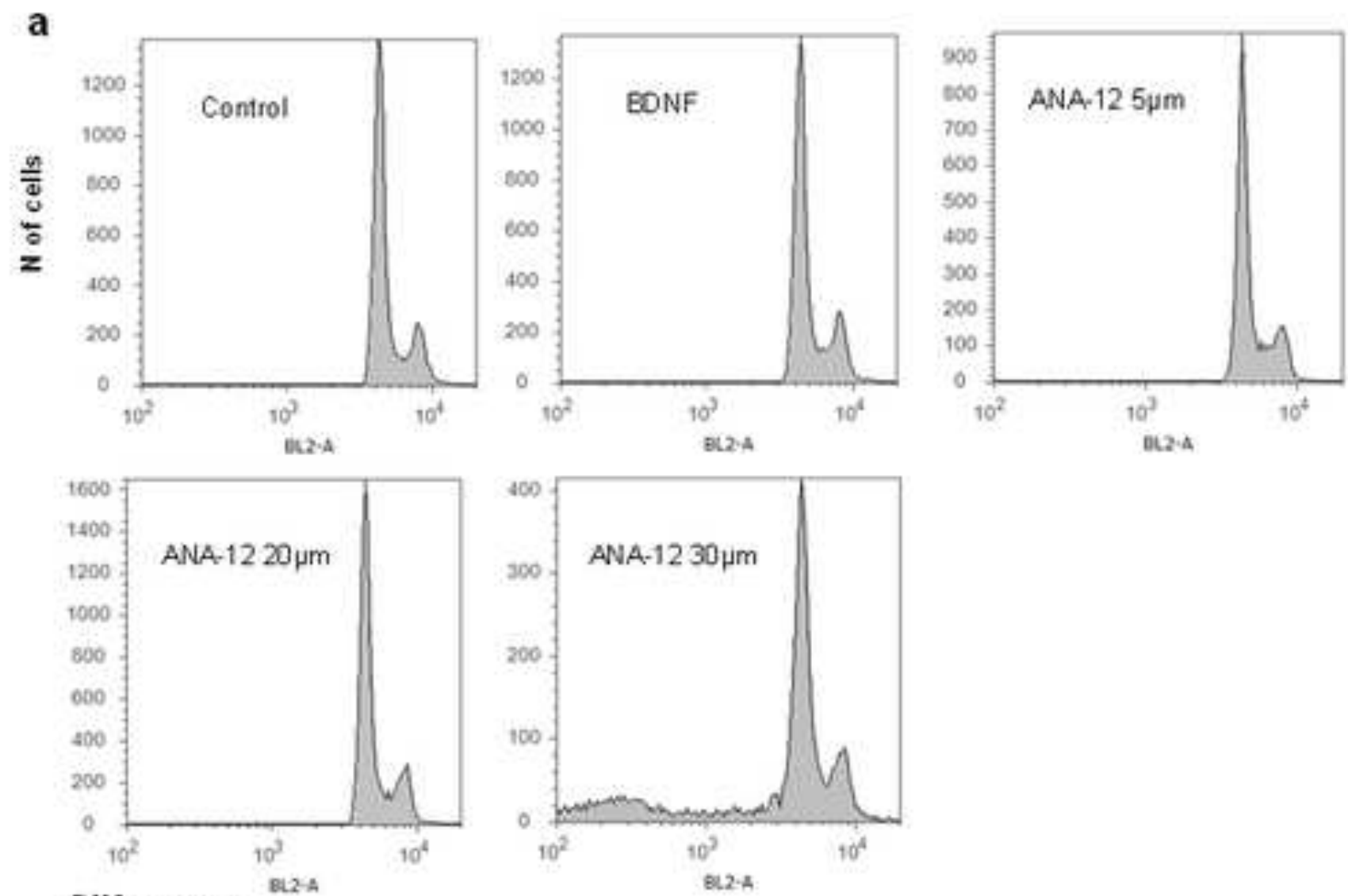

DNA content

b

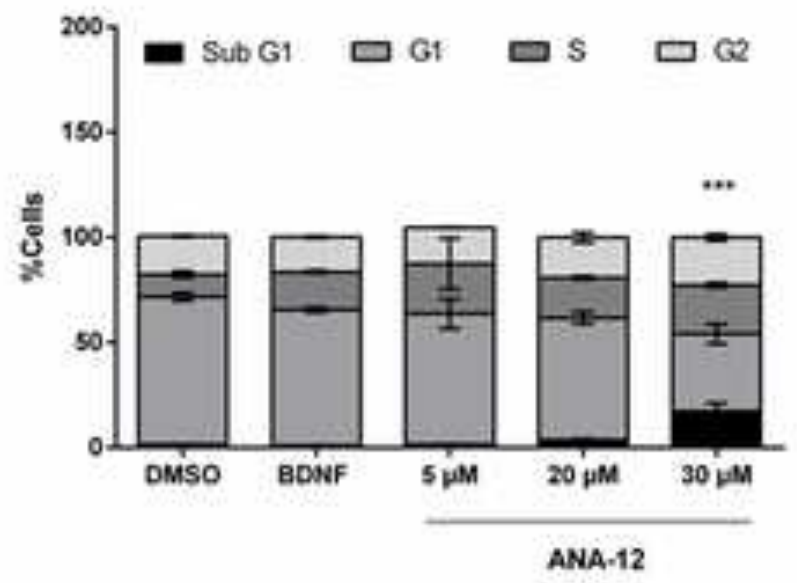

C

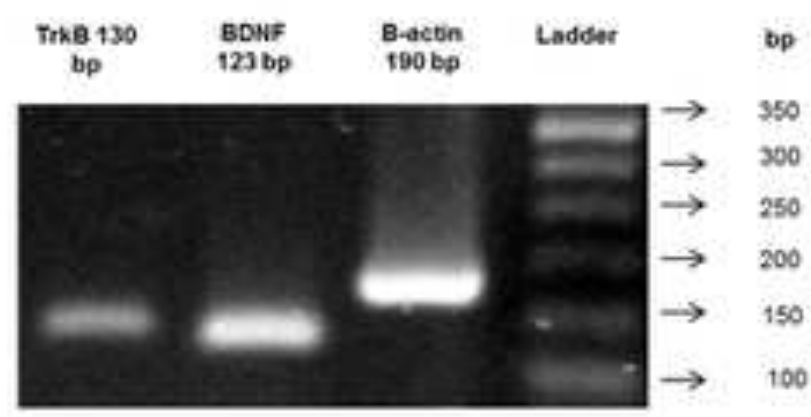

